\title{
Impact of territorial constraints on the optimization of forest accessibility. GIS Spatial Analysis for Quercus forests in National Park of Peneda-Gerês, northwest Portugal
}

\author{
Giovanni Pecora ${ }^{1}$, Nicola Moretti ${ }^{2}$, Susana Saraiva Dias ${ }^{3}$, Orlanda Póvoa ${ }^{4}$
}

\section{N F O}

Received 31 March 2014

Accepted 1 Oct 2014

Available on-line 6 Oct 2014

Responsible Editor: K. Rajkai

Keywords:

GIS, timber extraction, forest management, forest accessibility.

\begin{abstract}
$\underline{\text { A B S T R A C T }}$
ArcGIS software was used for timber harvesting planning in four (4) different mountainous forest areas of Peneda-Gerês National Park (PNPG), located in Northwest Portugal.

Orographic characteristics, such as slope and watershed systems features were considered. The different manual and mechanical timber extraction and concentration methods were also considered.

The different typologies of roads network to access forests were also introduced in the models.

The analysis allowed identifying forest areas with different accessibilities and orographic restrictions. Performed analysis also allowed the planning of additional roads necessary for timber extraction optimization, considering optimized site-by-site timber extraction methods. The proposal of accessibility improvement through new roads construction was also considered important for forest fire prevention and for fire direct combat. However, the present proposal of accessibility improvement is merely an academic exercise because nature conservation restrictions severely limit the construction of new forest roads.

This methodological approach should be tested in other mountainous forest regions throughout Europe.
\end{abstract}

\section{Introduction}

The GIS is a software technology that allows to locate and analyze objects and events that occur on the earth.

There are various software technologies used based on GIS, as well as experiences within forestry sciences based on the management of digital territorial data (Pira and De Natale, 1999) that were used to access road infrastructure network in the forest (Scrinzi et al. 1999). Increasingly, the SIT (Italia Territorial information system) have been used to identify forest areas subject to avalanche phenomena or forest fires based essentially on the evaluation of the land characteristics and forest cover (Ciolli et al., 1998, Ciolli et al. 1999a).

By combining and analyzing information from orographic type, infrastructure network and forest cover, cartographic models of analysis can be processed aimed to identify, site by site in the forest, the labor instruments and the work systems more rational in relationship to the land conformation and the road network features.

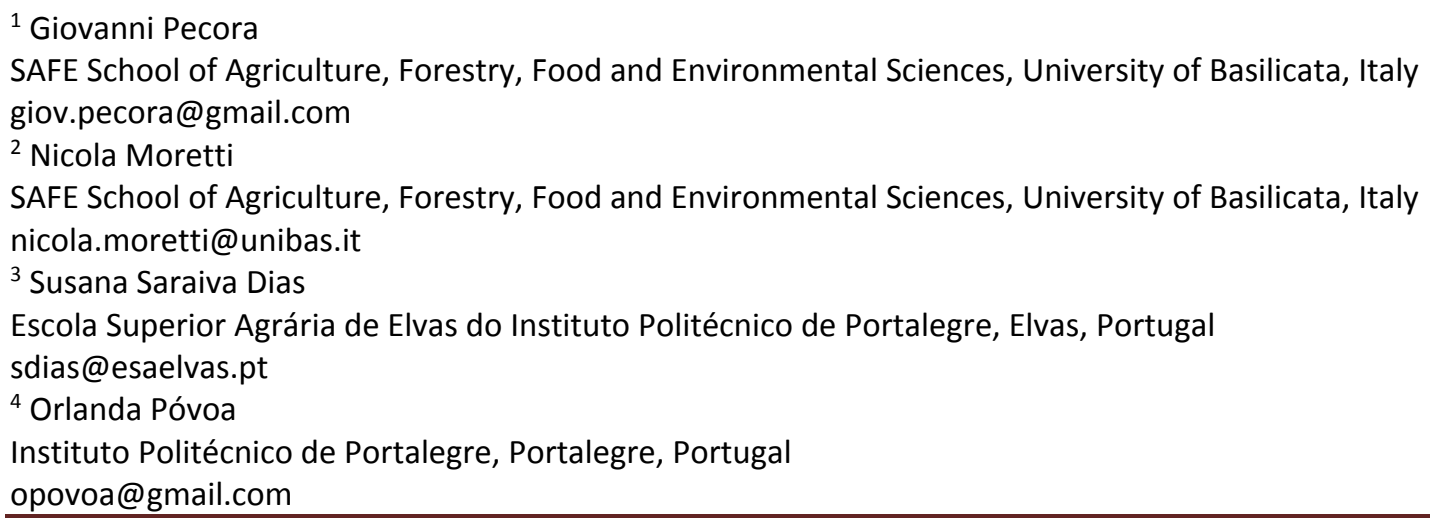


Oak forests from PNPG are protected by national and international laws, with high restrictions for human activities. So, it is important to state that the proposal of new roads is merely an academic exercise aiming to achieve research purposes.

This paper has as main goal to optimize the forest harvesting in European mountainous areas with the aid of geographic information systems (GIS). This approach was developed for the harvesting planning and timber concentration within four forested areas in National Park of Peneda- Gerês located between two regions, Minho and Trás-os-Montes, North Portugal.

\section{Materials and methods}

The four studied forest areas are located in Peneda-Gerês National Park belonging to the Viana do Castelo, Braga and Vila Real districts in Northwest of Portugal: Albergaria Forest, Beredo river Forest, Cabril river Forest, and Mau river Forest. All the considered forests are deciduous oak forests, allowing data comparison.

In the forest utilization planning, the factors that define the choice of forest machines and labor instruments are mainly the road network, land features (slope and accessibility), timber dimensions and, harvesting operations (harvesting systems and timber concentration systems). All GIS analysis were performed using ArcGIS 10 (ESRI, 2011).

\subsection{Slope analysis}

The slope analysis was performed using the DEM (Digital Elevation Model), and was then reclassified as percentage considering five classes according to Hippoliti (1994): 0-20\%, 21-40\%, 41$60 \%, 61-80 \%$ and $>80 \%$. The high gradients influence the new roads construction in forests, in fact land slopes above $60 \%$ were not considered for road construction, thus influencing the choice of timber harvesting and concentration systems, as shown in Figure 1.

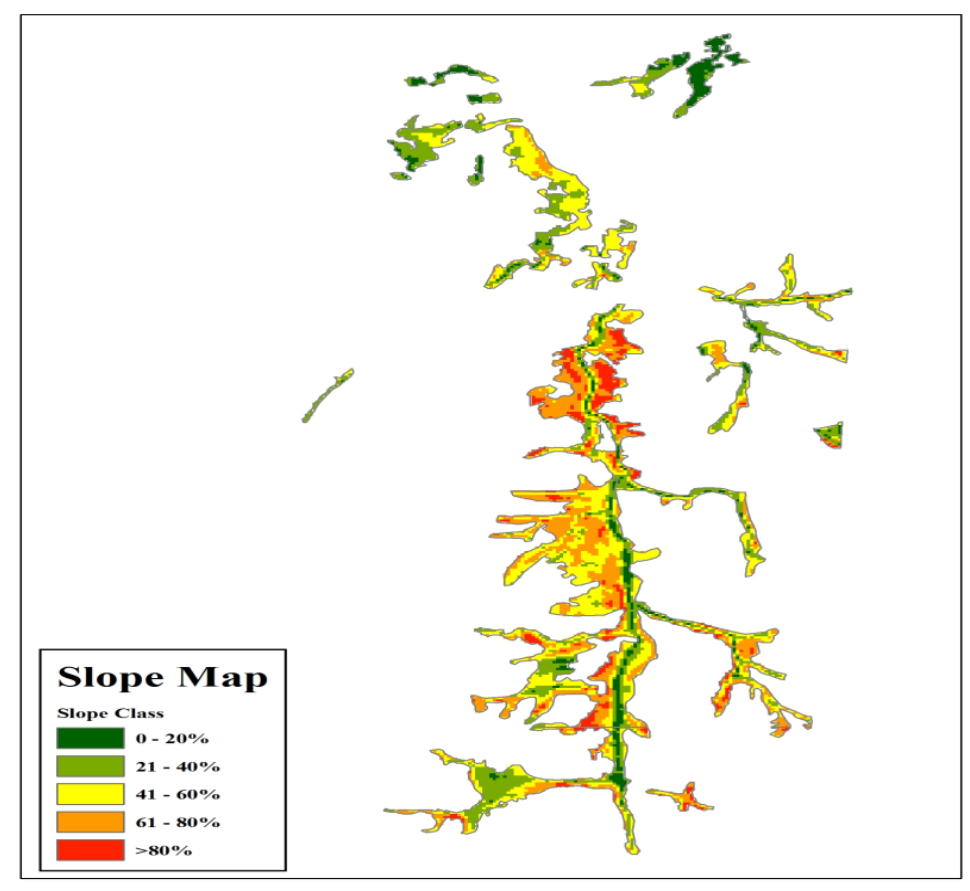

Figure 1. Example of slope classes calculated for Cabril river forest.

\subsection{Hydrographic network analysis}

This analysis focused on the rivers (and streams) presence in the forests, and their influence on the timber harvesting operations and new roads construction, in the same four different wooded area of Peneda-Gerês National Park. 
A shape file has been constructed for determination of river surface incidence on entire forest surface. The river disposition often not allowed an easy new road construction in the forest, as shown in Figure 4.

The shape file was made by editing the hydrographic layer of the Portuguese Institute for Nature Conservation and Forestry (ICNF), as shown in Figure 2.

The river surface has been calculated building a buffer with $15 \mathrm{~m}$ width. This parameter is a measurement average of the rivers width with the aid of ArcGIS measurement tool and Basemap imagery, by photo interpretation.

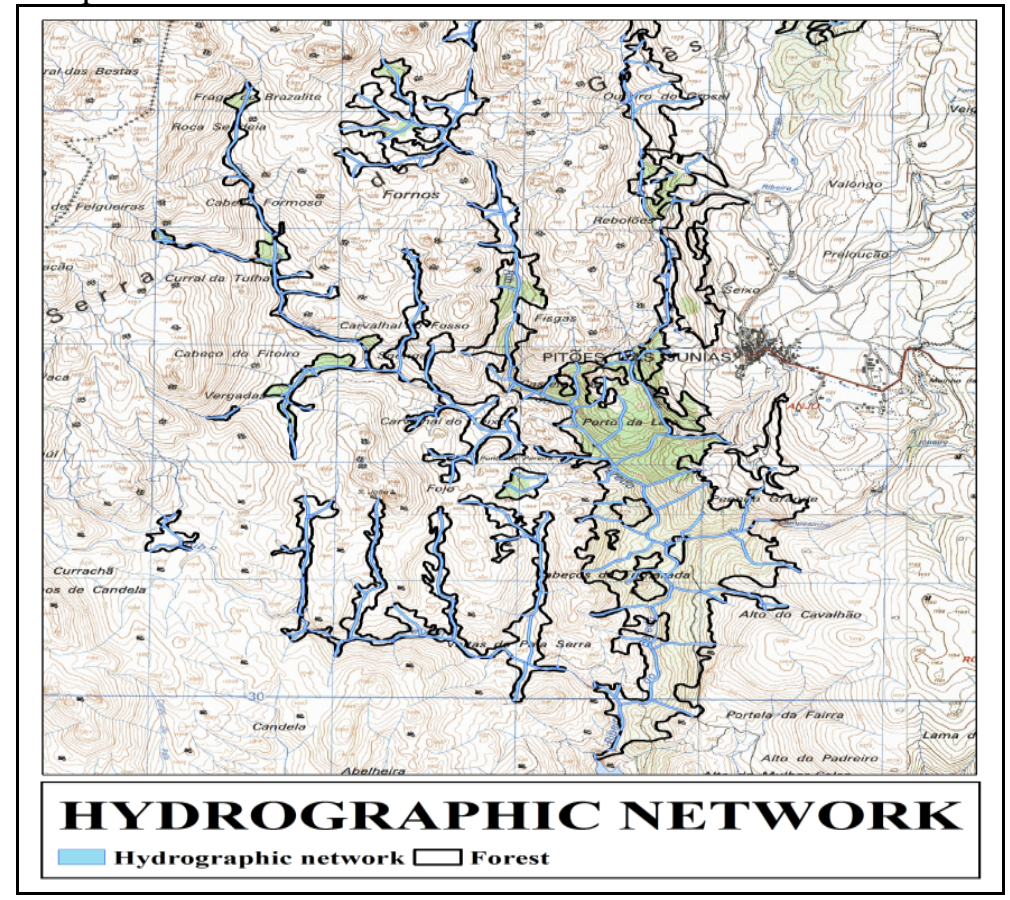

Figure 2. Example of hydrographic network in Beredo river forest.

\subsection{Road network analysis}

In the present study, it was proposed the development of a methodology to support the assessment of "timber harvesting road", in four different areas of Peneda-Gerês National Park, based on the determination of the forested land uses and the determination of the wooded land served by roads.

Two different road classifications have been used (ICFN and Hippoliti classification), but the features of roads are similar for each class.

Two shape files have been created for the determination of the roads already present in the forests, and the missing roads that could be constructed. In the first one the existing roads were classified according to ICNF as: main road, secondary road, motorized track and footpath, like in the Figure 3. The footpath classification was not considered in the analysis, because it was not usable for harvesting operations in forest. 


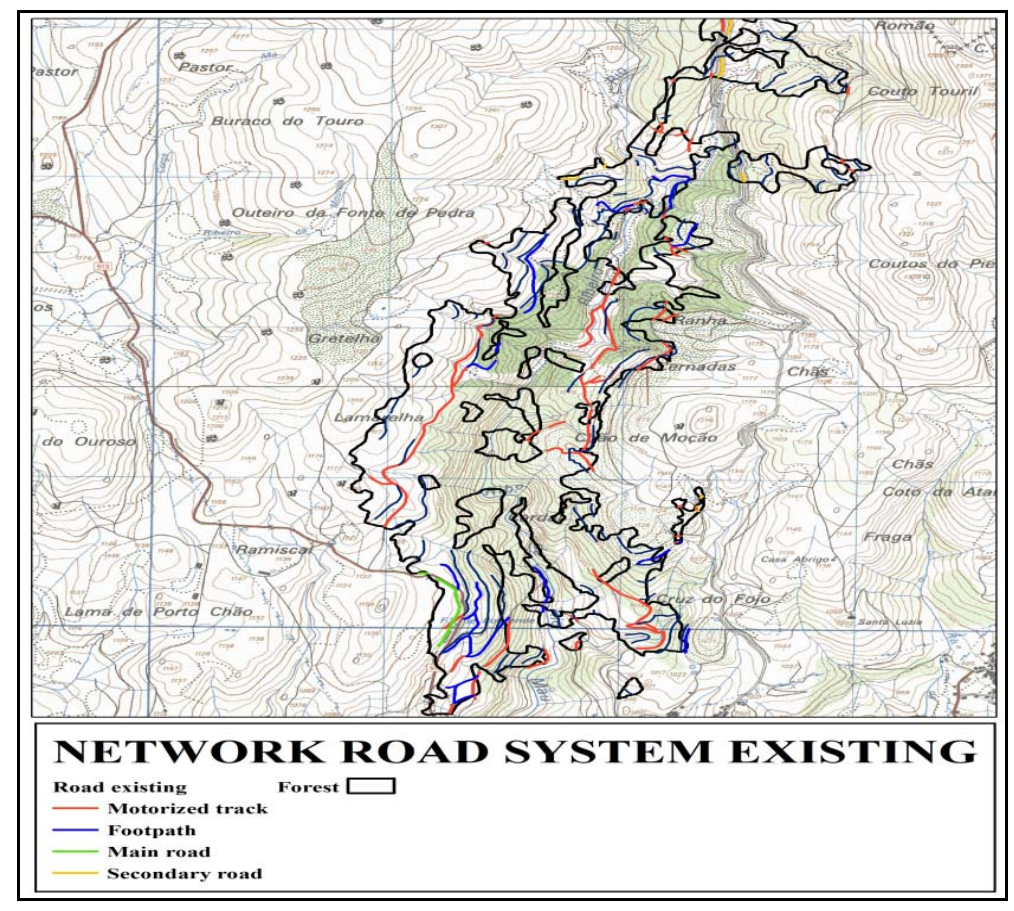

Figure 3. Example of existing roads network in Mau river forest.

The second shape file was created by digitizing the new roads along the contour lines (proposal of new road network system). The contour lines, with 25 meters distance, were obtained from DEM (Digital Elevation Model), with 20 meters resolution. New roads have been digitized, starting from the intersection of the contour layer and the existing roads layer (where it was possible), taking into account spatial constraints, such as hydrographic network and steep slopes, and they were classified according to Hippoliti classification (1994) as: main roads for truck, secondary roads for truck and roads for tractors or tracks, as shown in Figure 4. The new proposed road construction could also improve the fireman work in the forest. In fact, an efficient network road system could be helpful for timber removal, but also in fire prevention and fire combat interventions, allowing transit of road tankers for the direct intervention or vehicles used in the phases of power off. On this issue, the last report of rural fires from ICNB, Institute of Nature conservation and Biodiversity (2011), was considered. 


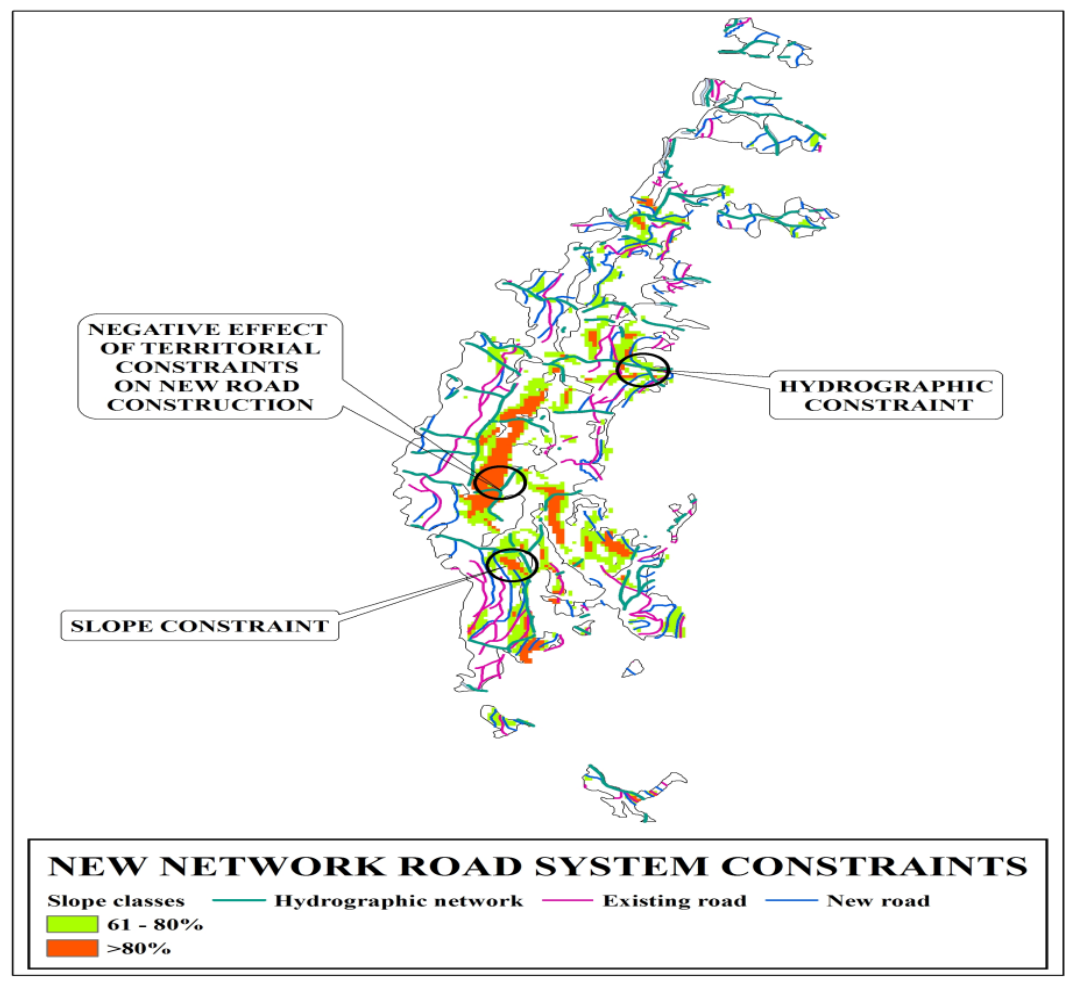

Figure 4. Example of new road system to be constructed in Mau river forest.

\subsection{Forest accessibility}

The forest accessibility analysis was performed by Path Distance tool (Spatial Analyst tool) to evaluate the different accessibility before and after the new road construction. These analysis were carried out, by relating network road system analysis (input raster or features source data), and slope analysis (input surface raster), having as spatial parameter a buffer of $100 \mathrm{~m}$, which was applied only for network road system (existing and new roads). The new road system was made by Merge tool (Geoprocessing tool) through merging of existing road and new road.

The buffer of forest accessibility was established according to Hippoliti 1994, which states that a forest is accessible if served by roads with a distance of $100 \mathrm{~m}$.

\subsection{Timber concentration and harvesting system}

The scheme proposed by Hippoliti (1994) takes into account several parameters, including slope classes, concentration system, cutting intensity, harvesting direction, timber dimensions and harvesting system. This was applied only in forests well served with roads, because the timber extraction cost was considered too high in areas without accessibility.

\section{Results and discussion}

The results obtained from the spatial analysis showed that the presence of roads in the forests in some areas was very poor or even absent. The road density in these forest varies from 0,5 to $5 \mathrm{~m} / \mathrm{ha}$ which is very low compared, for example, with Basilicata mountainous oak forest which have 2 to 15 $\mathrm{m} / \mathrm{ha}$ (Pecora et al., 2013).

With the proposed methodology there was a significant percentage increase of new roads, and therefore accessibility improvement in the wooded areas. In fact, the percentage increase of new roads was as follows: Albergaria forest $78 \%$, Beredo river forest $80 \%$, Cabril river forest $75 \%$ and Mau river forest $60 \%$. 
The new road construction might allow the increase of the road density, making forests more accessible. In fact, Figures 5 shows the accessibility before and after new road construction.

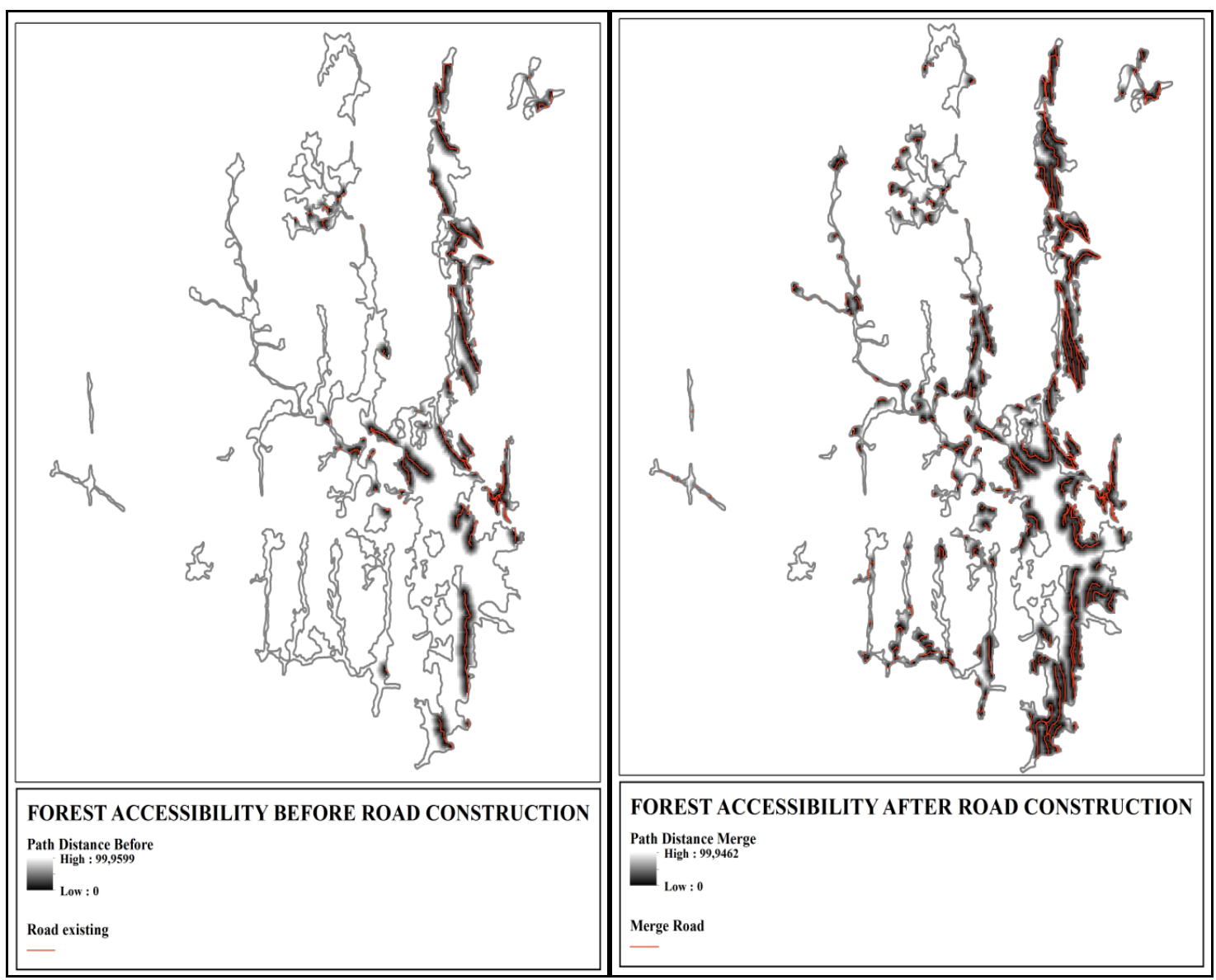

Figure 5. Example of forest accessibility before (left) and after (right) road construction in Beredo river forest. White areas have low or absent accessibility, black areas have good accessibility.

The analysis shows how the new road construction has influenced the forest accessibility. The white zone shows an area without an efficient network road system (low or absent accessibility), while the black zone shows an area with a good accessibility.

Adequate primary and secondary roads and trails should be planned with respect to density, routing and other physical characteristics such as width, slope and presence of suitable landings (Baldini et al, 2008).

We only proposed secondary roads or motorized tracks (roads for tractors), and logically it is not advisable to build major roads in the forest already established. As shown in Table 1.

Table 1. Proposal of new road construction intensity in 4 forests of Peneda-Gerês National Park

\begin{tabular}{|c|c|c|c|c|c|c|c|c|c|c|}
\hline \multicolumn{2}{|c|}{ Forest } & \multicolumn{4}{|c|}{ Secondary road } & \multicolumn{4}{c|}{$\begin{array}{c}\text { Motorized track } \\
\text { (Road for tractors) }\end{array}$} & $\begin{array}{c}\text { Total } \\
\text { Road }\end{array}$ \\
\hline Name & Area ha & $\begin{array}{c}\text { Length } \\
\text { m }\end{array}$ & $\begin{array}{c}\text { Before } \\
\text { m/ha }\end{array}$ & $\begin{array}{c}\text { After } \\
\text { m/ha }\end{array}$ & $\begin{array}{c}\text { Total } \\
\text { m/ha }\end{array}$ & $\begin{array}{c}\text { Length } \\
\text { m }\end{array}$ & $\begin{array}{c}\text { Before } \\
\text { m/ha }\end{array}$ & $\begin{array}{c}\text { After } \\
\text { m/ha }\end{array}$ & $\begin{array}{c}\text { Total } \\
\text { m/ha }\end{array}$ & $\begin{array}{c}\text { Length } \\
\text { m }\end{array}$ \\
\hline Beredo & 281 & 14159 & 0,2 & 21 & $\mathbf{2 1 , 2}$ & 9296 & 13 & 32 & $\mathbf{4 5}$ & $\mathbf{2 3 4 5 5}$ \\
\hline Cabril & 442 & 6110 & 2 & 23 & $\mathbf{2 5}$ & 4102 & 6 & 15 & $\mathbf{2 1}$ & $\mathbf{1 0 2 1 2}$ \\
\hline Albergaria & 429 & 9804 & 5 & 25 & $\mathbf{3 0}$ & 6594 & 2 & 15 & $\mathbf{1 7}$ & $\mathbf{1 6 3 9 8}$ \\
\hline
\end{tabular}




\begin{tabular}{|c|c|c|c|c|c|c|c|c|c|c|}
\hline Mau & 293 & 9075 & 1,5 & 31 & $\mathbf{3 1 , 5}$ & 5696 & 29 & 19 & $\mathbf{4 8}$ & $\mathbf{1 4 7 7 2}$ \\
\hline
\end{tabular}

Table 1 shows how the proposal for new road construction has influenced the road density, especially the motorized tracks (road for tractors). There have been considerable improvements of roads in the Mau river and Beredo river forests, much less in the other two forests.

The choice of different roads was carried out considering the existing roads, and it was decided to build secondary roads where they were not present, connecting to previous secondary roads.

The low road amount in some areas is due to the presence of territorial constraints, such as the hydrographic network, and steep slopes.

The analysis of territorial constraints showed that slope constraint has a bigger impact in Albergaria forest (139 ha, 32\% area forest) and in Cabril river forest (92 ha, 33\%) while in the other two forests had a minor importance, as shown in Table 2.

Table 2. Territorial constraints in 4 forests from Peneda-Gerês National Park

\begin{tabular}{|l|c|c|c|c|c|}
\hline \multirow{3}{*}{ Forest } & Total area & \multicolumn{2}{|c|}{ Hydrographic network } & \multicolumn{2}{c|}{ Slope } \\
& & \multicolumn{2}{|c|}{ Territorial constraint } \\
& ha & ha & $\%$ & ha & $\%$ \\
\cline { 2 - 6 } & 429 & 26 & 6 & 139 & $\mathbf{3 2}$ \\
\hline Albergaria & 281 & 79 & 18 & 24 & 5,3 \\
\hline Beredo & 442 & 48 & 17 & 91,6 & $\mathbf{3 3}$ \\
\hline Cabril & 293 & 29 & 9 & 13,2 & 4,2 \\
\hline Mau & & & & & \\
\hline
\end{tabular}

Hydrographic network covers all the forests. The main problem that hydrographic network creates for the new road construction, isn't the total area of coverage, but its spatial distribution in the forest; in fact, often it has a fan shape that covers almost the entire forest area (Pecora et al, 2013), as shown in Figure 2.

In fact, the forest managers need information about the potential impacts of roads on large areas to conduct cumulative effects analyses and watershed analyses for planning new road construction, and road maintenance (Luce et al., 2001; Switalski et al., 2004).

The main problem that withdraws from the spatial analysis is the connection of all restrictions, which cover a large part of the forest area.

The choice of concentration and harvesting systems are the same proposed by Hippoliti in 1994.

The guidelines for choosing the suitable concentration and harvesting system shall bring into relationships territorial parameter (slope classes) with dendrometric parameters such as, cutting intensity, harvesting direction and timber dimensions, and usable for forests well served by roads, in this case, after the proposed new road construction, because nowadays road density is very poor.

Hand-skidding, lightweight tractors with trailer, with basket or winch, drag with weighty tractors, drag with winches or with animals, are common systems used for timber concentration and harvesting in Basilicata region (Pecora et al 2013). These systems are used both downhill and uphill and could be used in Portuguese forests of Peneda-Gerês National Park.

Sometimes the forest companies used chute cut in half system, particularly the system that consist of half chutes joined end-to-end to form a continuous channel guiding the timber down a slope. The cable crane system could be used within the two classes with high slope where the forests are served by roads, however on these high slopes all systems are usually uneconomic. 
Moreover, from the analysis of last fire report of Rural and Forest fire in the National Network of Protected Areas (ICNB), year 2010, it has been established that the fire impact in Peneda-Gerês National Park is very high. In fact in the year 2010 there were 5 fires, 6362 ha of burned area, and an average of 1272,4 ha per year considering the 2005/2009 period. Most probably these fire areas could be lower with a denser road network, because, as already said; the road existing density is very poor. The proposed new road construction could serve both for fire prevention tasks and for vehicles traffic during fire fighting and in the phases of power off. In fact, the secondary roads could be useful as firebreaks, if the road width is longer than the height of the plants (trees or shrubs). Its effectiveness as firebreaks involves the maintenance of the two sides of the roads, performing strong thinning on shrubs and trees layers and grazing on herbaceous layer.

\section{Conclusion}

The proposed model had the goal to provide guidelines for the effective mechanization of forest harvesting, timber collection and additionally fire direct attack, directing the choice to the most suitable systems for different territorial conditions. But, the construction of new roads in PNPG oak forests is extremely difficult due to nature conservation restrictions. However, forest accessibility could be maintained/improved by the maintenance/restoration of old footpaths (and old oxcart paths) that could be used for occasional forestry interventions using manual and animal traction systems for individual small tree removal.

The oak forests from PNPG are protected by national and international laws, with high restrictions for human activities, in fact, Albergaria forest is considered the «crown jewel» of the Portuguese nature conservation, being one of the main reasons for the PNPG classification as a National Park; this forest has been classified by the European Council as a Biogenetic Reserve of the European continent. Moreover, the forest products extractions should obviously take in account nature Portuguese national conservation restrictions regarding protected species (flora and fauna) (Resolução do Conselho de Ministros n. $\left.{ }^{\circ} 11-\mathrm{A} / 2011\right)$.

The GIS spatial analysis could be a tool for the improvement and development of "woodcutter profession" and "fireman profession", in fact, by using these advanced software systems (GIS tools), forest companies (private or public) may optimize forestry management interventions.

\section{Acknowledgment}

The authors acknowledge Portuguese Institute for Nature Conservation and Forestry (ICNF), Peneda-Gerês National Park, for the disposal of basic cartographic information layers considered in this paper.

\section{References}

Baldini S., Cavalli, R, Piegai F, Spinelli R, Di Fulvio F, Fabiano, F., Grigolato S, Laudati G, Magagnotti N, Nati C, Picchio R. 2009. Prospettive di evoluzione nel settore delle utilizzazioni forestali e dell'approvvigionamento del legname. Atti del Terzo Congresso Nazionale di Selvicoltura. Taormina (ME), 16-19 ottobre 2008. Accademia Italiana di Scienze Forestali, Firenze, p. 717-728.

Ciolli M, Tabarelli S, Zatelli P .1998. 3D spatial data integration for avalanche risk management. In: International symposium on GIS: "Between Visions and Applications". Stuttgart, International archives of photogrammetry and remote sensing 31 (4): 121-127.

Ciolli M, Mascarell P, Sguerso D, Zatelli P. 1999. Valutazione tramite fotogrammetria e GIS della dinamica della copertura forestale e della provvigione legnosa. In: Atti della $3^{\circ}$ Conferenza nazionale delle Associazioni Scientifiche per le informazioni Territoriali ed Ambientali, Napoli 1: 589-594.

ESRI 2011. ArcGIS Desktop: Release 10. Redlands, CA: Environmental Systems Research Institute.

Hippoliti G. 1994. Le utilizzazioni forestali. Editrice CUSL, Firenze. pp 19-20, 22, 85-89,92-96,97

ICNB, Instituto da conservação da natureza e da biodiversitade 2011. Relatório de Incêndios Rurais / Florestais na RNAP 2010. 
Luce C. H. and T. A. BLACK. 2001. Effects of Traffic and Ditch Maintenance on Forest Road Sediment Production, The Seventh Federal Interagency Sedimentation Conference, Reno, Nevadad, March 25-29, 2001, p.V67-V74

Masoni M, Dibari C., Siddi E. 2005. I Sistemi Informativi Territoriali. Provincia di Pisa. [online] URL: http://sit.provincia.pisa.it/sisterims/html/Corso_SIT/Corso_pagina_iniziale. Htm

Pecora G, Moretti N, Saraiva-Dias S, Póvoa O. 2013. Geographic information systems (GIS) as a tool for the optimization of timber harvesting in mountain regions forests. VII Iberian Congress of Agricultural Engineering and Horticultural Sciences, ISBN - $10 \quad 84-695-9055-3$, http://sechagingmadrid2013.org/geystiona/adjs/comunicaciones/272/C04640002.pdf

Pira G, De Natale F. 1999. La gestione dei dati digitali territoriali nell'attività forestale. Alcune esperienze di programmazione come integrazione nell'uso dei GIS. Dendronatura 2/99, Associazione Forestale del Trentino, Trento. pp. 34-37.

Switalski,T A, Bissonette J A, Deluca T H, Luce C.H, Madey MA. 2004. Benefits and Impacts of Road Removal, Frontiers in Ecology and the Environment, 2(1): 21-28. 